\title{
HIBRIDITAS BUDAYA SEBAGAI BENTUK TEGANGAN DAN NEGOSIASI LOKAL- GLOBAL
}

\author{
Abdul Rahim \\ abdulrahim09bi@gmail.com \\ Fakultas Sastra Universitas Nahdhatul Wathan Mataram Nusa Tenggara Barat

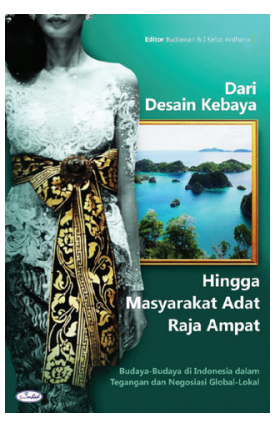 \\ Judul Buku: Dari Desain Kebaya Hingga Masyarakat Adat Raja Ampat - \\ Budaya-Budaya di Indonesia \\ Dalam Tegangan dan Negosiasi Global-Lokal \\ Editor : Budiawan dan I Ketut Ardhana \\ Penerbit : Penerbit Ombak \\ Halaman : 393 Halaman \\ ISBN : 602-258-507-4 \\ Resensi : Abdul Rahim \\ Budaya-budaya yang disebut genuine \\ atau bentuk hibriditas yang muncul ketika \\ bersentuhan dengan globalisasi, tidak jarang \\ memunculkan stigma bahwa tradisi sudah \\ terkikis dan karakater masyarakat sudah \\ memudar dan kehilangan jati diri. Ketika tradisi \\ menjadi sesuatu yang amat dipertahankan, \\ konteks pembangunan dengan modernitas \\ menjadi kekuatiran dengan perubahan pola \\ perilaku dalam masyarakat yang masih \\ mempertahankannya sebagai sebuah pakem. \\ Akan tetapi, dekonstruksi atas pakem itu sendiri \\ merupakan upaya membentuk hibriditas \\ budaya. Di sinilah globalisasi dimaknai sebagai \\ ancaman, terkait kemudahan, efektivitas dalam \\ pelaksanaan tradisi yang tidak lagi mengikuti \\ pakem. Padahal tegangan dan negosiasi atas \\ hal itu menjadi hal mutlak yang muncul sebagai \\ efek dari lokal-global yang bersentuhan dalam \\ kehidupan manusia sehari-hari secara tidak \\ disadari. \\ Tema-tema seperti itu menjadi ulasan \\ dalam buku ini yang disajikan dalam empat \\ bagian besar. Bagian pertama, Keintiman, \\ Tubuh Perempuan, dan Seni dalam Masyarakat \\ yang Terbelah, berisi sembilan artikel hasil \\ mini riset tentang budaya visual dan tradisi \\ (lokalitas) yang bersentuhan dengan budaya \\ populer. Bagian ini terkait lokalitas dan \\ budaya populer hasil persentuhan dengan \\ globalisasi yang menjadi pokok bahasan dari \\ masing-masing penulis, mulai dari relasi \\ keintiman yang perlu didefinisikan ulang \\ dalam masyarakat skizofrenia, lalu bagaimana \\ tubuh perempuan dalam joged goyang ngebor \\ Bali menjadi bentuk erotisasi yang justru \\ kehilangan identitas sebagai sebuah seni. \\ Artikel selanjutnya tentang Penjor sebagai \\ sebuah media ritual justru menjadi bentuk \\ komodifikasi yang menjadi ajang untuk \\ menunjukkan kelas, desain kebaya yang \\ membentuk hibriditas dalam sebuah desain \\ milik Anne Avantie terkait dengan negosiasi \\ global-lokal, Sanggul yang membutuhkan \\ redefinisi dalam masyarakat Jawa kontemporer \\ tentang sebuah mode dalam masyarakat kelas \\ menengah. Selanjutnya tentang visualisasi \\ ragam hias adati batik Jawa Timuran sebagai \\ identitas kultural, wayang topeng Malang yang \\ menunjukkan peran estetik dalang, selanjutnya \\ tentang pertunjukkan Caci Manggarai di Nusa \\ Tenggara Timur sebagai sebuah seni tradisi yang
}


beralih fungsi menjadi media kampanye atau hal-hal yang berkaitan dengan politik elektoral, dan musik lokal Ambon dari tahun 1930-an hingga 2000-an yang menegosiasi modernitas. Keragaman artikel pada bagian pertama ini dikumpulkan dalam satu tema terkait lokalitas yang mempertahankan identitas, sesuai dengan komposisi pembahasan yang menunjukkan identitas yang terbelah menghadapi yang global dengan beragam argumen teoritis yang mendasari tulisan-tulisan tersebut.

Pada bagian kedua terdiri dari tujuh artikel terkait Media (baru), Politik, dan Wacana Identitas. Media (baru) yang disajikan penulis di antaranya yaitu meme comics sebagai bentuk resistensi, Dalam hal ini meme yang dibuat sebagai resistensi terhadap gerakan FPI (Front Pembela Islam), lalu komparasi antara jurnalisme cetak dan jurnalisme online yang diungkapkan dalam sebuah teks pada kolom Udar Rasa Kompas oleh Bre Redana. Bre Redana dalam tulisannya mengungkapkan jurnalisme cetak sebagai bentuk adiluhung, yang dioposisi binerkan dengan jurnalisme online. Artikel Selanjutnya yaitu tentang remaja yang dihegemoni teknologi multimedia, dimana hegemoni yang dimaksudkan penulis terkait keterpaparan remaja yang selalu update dengan teknologi dan menjadi pemburu kebaruannya. Selanjutnya tentang logika agama yang dimediatisasi dalam pemberitaan kasus Dimas Kanjeng, mediatisasi yang dimaksud penulis dari konsep Stig Hjarvard terkait dengan logika dari para murid Dimas Kanjeng yang terjerat dengan media yang memberitakan kasus penggandaan uang yang menjadi motif penipuan yang dilakukan.

Masih dalam bagian kedua artikel selanjutnya menyajikan tentang wacana etnisitas dan agama dalam gelaran pesta demokrasi. Dalam politik elektoral, wacana etnisitas dan agama masih menjadi isu krusial untuk menarik pemilih sehingga terjadi keterbelahan dalam memposisikan diri di antara pemilih dengan digaungkannya isu etnisitas dan agama. Selanjutnya artikel yang menganalisis serial animasi "Doraemon" di RCTI terkait kelas menengah yang ditampilkan dalam serial tersebut dalam wacana pembangunan yang digaungkan orde baru. Terakhir yaitu artikel tentang relasi konsumen dan merek dalam dimensi simbolik, sosial, dan politik. Merek sebagai konsumsi simbolik atas barang menjadi identitas yang dikonstruksi dan simbol kelas. Pengelompokkan artikel pada bagian kedua buku ini merupakan analisis atas fenomena yang menjadi ketertarikan penulis dari media yang berelasi dengan konteks keseharian manusia. Media baru ataupun wacana identitas masih menjadi isu-isu hangat dalam riset cultural studies sehingga beberapa kasus yang disajikan pada bab kedua ini dapat menjadi referensi untuk riset-riset lanjutan dan studi kasus yang lebih kompleks.

Pada bagian ketiga tema yang diangkat Adat dan Agama dalam Wacana Pembangunan dan Pariwisata, terdiri dari enam artikel yang membahas tentang pariwisata dan komodifikasi budaya yang terjadi di dalamnya. Konteks pertama bagaimana perspektif budaya Bali memandang revolusi mental yang digaungkan dalam pemerintahan Jokowi sebagai sebuah refleksi kritis, bahwa mental yang dimaksudkan dalam kabinet kerja Jokowi tidak seiring dengan perspektif budaya Bali yang mengedepankan kebersamaan. Artikel kedua tentang Raja Ampat sebagai sebuah industri pariwisata yang disebut sebagai "harta yang digadai" dalam kepungan modernitas. Modernitas yang dimaksud terkait dengan maraknya industri pariwisata yang mengepung masyarakat adat Raja Ampat justru menjadikan mereka sebagai masyarakat yang tidak lagi memiliki identitas, dan lahan yang semakin banyak dikuasai investor. Selanjutnya yaitu tentang wacana syariah yang digaungkan secara massif di bawah kuasa Dewan Syariah Nasional MUI (Majelis Ulama Indonesia) yang menjadi penjaga gawang inisial syariah di setiap produk ataupun program pemerintah dan swasta yang membutuhkan legalisasi atas wacana syariah. Identitas keislaman melalui wacana syariah menjadi sebuah tujuan yang diidamkan dengan membentuk masyarakat yang homogen yang berlandaskan syariat Islam, tetapi yang terjadi justru manipulasi kesadaran atas wacana syariah itu sendiri 
yang jauh dari konsep syariah dalam Islam itu sendiri.

Artikel selanjutnya tentang komodifikasi jilbab dalam produk Nike hijab untuk perempuan yang sering berolahraga sebagai gaya hidup. Jilbab sebagai pakaian islami dalam masyarakat muslim tidak menjadi halangan untuk tetap tampil sporty dengan produk dari Nike yang menyasar masyarakat muslim kelas menengah melalui produk hijab tersebut. Selanjutnya tentang budaya dan agama dalam pengembangan pariwisata. Budaya dan agama dalam konteks pariwisata dikembangkan sebagai landasan untuk mempertahankan identitas masyarakat di ruang pariwisata yang saat ini justru banyak menimbulkan ketimpangan dengan motif kesejahteraan ataupun motif ekonomi yang menjadi tujuan, tetapi pada praktiknya jauh dari itu. Artikel terakhir pada bagian ketiga menyajikan tentang standarisasi karakteristik siswa pintar sebagai kekerasan simbolik pada siswa introvert. Komparasi dengan siswa ekstrovert yang aktif menjadikan siswa introvert dipandang sebagai kelas dua dalam lingkup pendidikan sekolah. Siswa introvert yang dipandang individual, tidak mempunyai kepekaan sosial, menjadi pandangan yang salah dalam dunia pendidikan. Kekerasan simbolik dalam pengategorisasian siswa dari karakteristik seperti itu tidak memiliki dasar teoritis yang mendukung argumentasinya.

Keragaman tema pada bagian keempat ini menjadi sebuah referensi kritis menyikapi fenomena dalam kehidupan sehari-hari tentang kekerasan simbolik ataupun doxa yang sering digaungkan dalam relasi kuasa antara adiluhung dan rendahan dari sudut pandang tertentu. Begitu juga dengan komodifikasi yang hampir di semua lini kehidupan sudah menjalar menjadi sebuah sistem yang dikapitalisasi pemodal dalam upaya memenuhi kebutuhan akan eksistensi diri ataupun pemenuhan gaya hidup.

Bagian terakhir dalam buku ini membahas tentang pembangunan wilayah, ruang publik dan desain hunian. Tiga artikel terakhir pada bagian ini terkait dengan konteks ruang publik misalnya pada ruang publik warung kopi sebagai ruang demokratis di Makassar sebagai arena pembahasan politik ataupun demokrasi. Selanjutnya desain hunian masyarakat Bali kontemporer dalam bayangbayang homogenisasi dan universalisasi. Hunian homogen yang dimaksudkan terkait dengan hunian masyarakat Bali yang tidak lagi memperhatikan konsep hunian dahulu yang mengedepankan pertimbangan budaya dan agama yang menjadi landasan untuk pembangunan rumah. Sementara masuknya industri properti menjadikan hal itu terkikis dan hunian homogen yang menjadi pilihan terkait juga lahan yang semakin menyusut. Sedangkan kajian budaya dalam konteks pembangunan wilayah perspektif penulis dalam buku ini terkait posisi kajian budaya sebagai disiplin ilmu yang memandang wilayah kajian budaya dalam konteks masyarakat Indonesia secara umum dan lokalitas secara khusus memiliki sudut pandang tersendiri sebagai disiplin llmu yang emansipatoris dalam perkembangan keilmuan. Pembangunan wilayah yang dimaksud terkait dengan integrasi disiplin keilmuan dalam berbagai bidang yang dikaitkan juga dengan konteks budaya dan lokalitas di suatu wilayah.

Dua puluh lima artikel dalam buku ini sebagai buah pemikiran dari perpaduan dua program studi Kajian Budaya (cultural studies) Universitas Udayana dan Kajian Budaya dan media Universitas Gadjah Mada menyajikan perspektif kritis dalam lingkup budaya, media (baru), lokalitas yang bersentuhan dengan globalisasi, pembangunan pariwisata, ataupun kajian kritis tentang ruang publik. Argumentasi teoritis dalam sudut pandang cultural studies menjadi pijakan sebagai kajian multidisiplin dalam buku ini. Meskipun beberapa artikel dalam buku ini pun tidak terlepas juga dari kajian Antropologi klasik dalam bentuk eksotisasi budaya yang mesti sesuai pakem, dan menolak modernitas ataupun ambiguitas budaya dalam persentuhan lokal-global itu sendiri. 